" At the time of his death he bad been for sone months a valuable: assistait and member of the Boston Society of Natural History, where many of his works remain to speak for themselves. Among his asscciates. there he was distinguished for his geniality of manner and never-failing radiness to assist younger students. At the time of his death his fame and forcign correspondence were somewhat extended, and he was actively engagec in the preparation of materials for an illustrative cabinet of the Natuial History of his native State. He had published from time to time in the Caramin Exronoligist and the Proceedings of the Natural History Society carefully elaborated results of his work, and contributed to various other periodicals devoted to his favonite branch of investigation. His fine private collection of insects, principally of the Colcoptcrous Order, in accorclance with his expressed determination, form a part of the Muscum of the Society to which he was attached, and is in itself no mean. monument to his momory:

F. G. S.

"Mr. Sprague was elected a member of this Society May 5:h, 1860."

\title{
CORRESPONDENCE.
}

\author{
RHAGIUM LINEATUNE.
}

DEAR SIR,-

In reply to Mr. W. V. Andrew's enquiry, I would say that the above insect breeds wider the bark of pine stumips. I have good reasons for thinking that it completes its transformations in Septemfor and bybemates until the following spring. I had long expected such to be the case from funding it in February and March, both living and deach, in the calvity formed by the larva in which to pupate. But in September, 1874, I found numerous spcimans of the beetle that had just appeared, many of then not mature in color, and with them several specimens of the pupae.

H. L. Moooy, Malden, Mass.

\section{DEAR SIK,- -}

Mr. Andrews inquíres, page 80, about Rhagium lineatum Oliv. The habits of this common species are well known to collectors of Coleoptera. Harris says, Ins. Inj. to Veg., p. 116: "These grubs (larvae of Rhagium) live between the bark and the wood (of pines) often in great numbers cogether, and when they are about to become pupae, each one surrounds isself with an oval ring of woody fibres, within which it undergoes its 
tratusformation. The beetle is mature before winter, but does not leave the trce until spring." I can personally vouch for the accuracy of the above, having often uncovered the beetle both in the fall and winter, as well as in the spring. It is ready to fly upon the advent of wam weather, and there were unquestionably other individuals about besides those observed on the church walis. This species, curious in other respects, furnishes also in its habits of hybernating a rather remarkable exception to the gensal rule among the Ceranuycidae. Most species of this family in this latiude pass the winter in the larval stage. During many successive winters' collecting I have met with no other species in its mature form. Scveral years since a Jiving specimen of Miroclylus gazellula Hald. was dug out of the bark of a living white oak, quite late in October, where it would doubtless have passed the winter inonths. Mr. E. P. Austin tells me, in a letter written at the time, of finding a specimen of Graphisurus pusillus Kirby, I think it proved to be, while sifting leaves in the winter of '73-'74. The only other instance which 1 now remember of the cccurence of a Cerambycide in winter is given by $H$. F. Fay, of Columbus, Ohio, in the Proc. Ent. Soc. of Phil., 1, p. 198, in an articie on "Winter Colfecting." He says: "The oniy Loryicom I have met with is a single specimen of Cyrlophorus niger $\mathbf{L}$ cc., or a var. of Clytus albofasciatus Grey."-_-_"It was found"-_-_."in the solt nood of a decaying elm."

F. Planchard, Lowell, Mass.

\section{DF,AR SiR,-}

In answer to Mr. Andrews' enquiry about Rhagium lineatum, in CAx, E.v., No. 4, I will say that I have found thousands under the bark of pine logs during the fall and at various times until the early summer months. The larva, pupa and imago are frequently found all at one time and under the bark of the same $\log$, and $I$ have at this time a bottle of specimens gathered in November from under the bark of a Jersey pine log not twenty niles from Mr. Andrews' residence.

A. S. Fillek, Ridgenood, Rergen Co, N. J.

ON TILE USE OF CYANIDE OF POTASSUMI.

We have been favored with a letter from Mr. J. E. Chase, of Holyoke, Mass., in reference to the use of boltles containing Cyanide of Potassum for catching and killing moths. Mr. C. encloses a spccionen label such as 
he attaches to bottles and distributes among those of his friends who are disposecl to help him in making captures. We append this for the bencfit of our readcrs:

\section{POISON.}

Directions How to Catce Molhs, itc.-The contents of the bottles are prepared by dissolving Cyanide of Potassium in water, and pouring into the bottle to the depth of half an iich; then drop in Plaster Paris until it thickens, and let it stand until hardened, keeping it CoRred. To catch moths with it, the best way is to take sugar from a molasses hogshead and mix with water, making it thick; spread this mixture on old posts, or trunks cf trees, fences, zec., for two or three days. When the moths begin to scent the sugar, provide jourself with a small lantern giting light only on one side; visit each post and tree, and you will find moths by letting the light shine on the swcetened places. Then hold the botte under one of them, and it wiil dart cr fall into it; cork immediatcly or it will $n_{y}$ out. Then put the botte in your pocket, and use another bottle to catch the next one, and by that time the first bottle will be ready for use again. You can thus visit each post, and when you reach the last one it is better to put the moths into a box, so that the new ones will not spoil them by flying among them. Some persons dip old rags into the syup and hang them up to attract the moths.

Drin SIR, -

From a friend in the neighborhood of Salt Lake, Utah Territory, I received a small lot of Lepidoptera, and as collectors would no doubt be pleased to learn something of the fauna of that locality, I will givt you a list of the insects received, viz:

Papilio daunas Boisd,

Pieris protodice Boisd. \& Lec.,

Anthocaris ausonides Boisd.,

Colias eurytheme Boisd.,

Vanessa antiopa Linn.,

P’yrameis caryae Hübn.,

Lycaena anna,

Chrysophanus helloides Boisd.

Of Platysamia gloverii I recsived two examples, both males, and as there were none of $\mathbf{P}$. cccropia among the lot, I would take it to be a proof that gloverii is not a form of that species. Besides the differences 